\title{
LOGISTICS AS A TOOL TO IMPROVE THE COMPETITIVENESS OF DHL SERVICES
}

\author{
JÓZEF PERENC \\ University of Szczecin, Faculty of Management and Economics of Services, POLAND \\ e-mail: jozef.perenc@wzieu.pl
}

\begin{tabular}{|c|c|}
\hline $\begin{array}{l}\text { RECEIVED } \\
\text { ACCEPTED }\end{array}$ & $\begin{array}{l}18 \text { January } 2018 \\
2 \text { September } 2018\end{array}$ \\
\hline $\begin{array}{l}\text { JEL } \\
\text { CLASSIFICATION }\end{array}$ & D2 \\
\hline KEYWORDS & service logistics, DHL's competitiveness \\
\hline ABSTRACT & $\begin{array}{l}\text { The article presents the role, tasks and functions of logistics in improving competitiveness of courier compa- } \\
\text { nies. The author has presented and justified the need to support the process of managing modern companies } \\
\text { with the use of logistics tools. Next, the entry of DHL to Europe and Poland as well as the development of the } \\
\text { company's market strategy have been presented. The latter part of the article describes the quality research } \\
\text { regarding the most important courier companies on the Polish market. Moreover, the size of the investments } \\
\text { necessary in 2018-2025 to strengthen this courier company's competiveness were estimated on the basis } \\
\text { of the current financial results. }\end{array}$ \\
\hline
\end{tabular}

\section{Introduction}

The courier service industry plays a prominent role in logistics. Its basic objective is delivery of a parcel to the end customer at the right place and time. The service should be carried out promptly, professionally, and satisfy the needs of the most demanding customer. In the currently competitive courier service market, DHL aspires to provide and develops such services. 


\section{The essence of modern logistics}

According to P. Blaik, logistics is the process of exchanging data, information, and goods between contractors, as well as adequate control leading to effective planning of integrated logistics systems in this process (Blaik, 2001, pp. 20-22). The creation of new goals in logistics is intended to help solve new practical issues concerning strategy of given companies and individual customers. Thanks to the introduction of basic logistics tools to every business strategy, it becomes possible to obtain a new, better quality that guarantees acquisition of new customers, and thus the chance to become the leading operator in the logistics market.

Today, there can be observed widespread internationalization of logistics tasks and functions in the sphere of modern economy. This applies to both the structure, as well as wider logistics activities. In order to improve company efficiency, it is advisable to cooperate in larger economic systems, e.g. the European Union, where cooperation with partners in the supply chain called "Eurologistics" is characterized by:

- framework conditions for the functioning of the economy of particular countries due to the creation of a European "Common Market",

- introduction of agreed operating structures including appropriate legal, organizational and technical regulations on this market( Szpon, Dembińska-Cyran, Wiktorowska-Jasik, 2005, pp. 13-14).

M. Ciesielski attributes similar importance to logistics, which he defines as commercial performance of forwarding, transport and storage services as well as related services, and processes supporting the flow of goods between the links in the supply chain (Ciesielski, 2005, pp. 13-14). W. Rydzkowski (2011) complemented logistics functions with terminal repacking services, foiling, minor repairs and creation of promotional sets. Similar definitions were included by K. Rutkowski and I. Dembińska in their textbooks on logistics (Rosa, Jedliński, Chrąchol-Barczyk, 2017, pp. 17-24). Another author, J. Szpon defines the concept of logistics in accordance with the 7R's principle (Szpon, Dembińska-Cyran, Wiktorowska-Jasik, 2005, pp. 13-14):

- the right product,

- the right quantity,

- the right condition,

- the right place,

- the right time,

- the right customer,

- the right price.

On the basis of this rule, enterprises strive to fully meet the needs and requirements of customers, which is the main goal of every company. The introduction of new strategies, solutions, technologies and innovations is becoming an indispensable cycle of life and development of every company

\section{The need to support modern company management with logistics instruments}

Logistics management of modern enterprises is based on the process of making the right previously agreed decisions by people who have been designated to do so in order to effectively optimize the entire supply chain process. Striving to achieve the desired goal by optimizing company costs without compromising on manufactured product quality, ensures effective service throughout the rational business management process. In order to properly manage the whole process, companies use appropriate logistics instruments which include, among others: 
- planning the entire process, from beginning to end,

- efficient distribution of information,

- continuous process monitoring,

- optimal planning of unit process,

- coordinating the work of given entities,

- effective and efficient customer service (Więcerzycki, 2009, pp. 260-285).

The competition taking place in currier service, transport, shipping and logistics market (TSL) is particularly important for any company that provides services in this industry. Thanks to fierce competition, every company (including DHL) wants to constantly improve and apply the latest solutions (new strategies), implement new methods and instruments to meet customers' requirements, which is the main goal of every company, as well as perform services at the highest level, which, in turn, leads to the company becoming a leader on the TSL market. Implementation of innovative logistics and marketing tools, optimization of information technology, more efficient data transfer, providing staff with training in order to acquire new skills, as well as many other elements that have contributed to more effective management of company structures in order to win new customers who make use of services offered by other competitive companies, and those who are new on the market, will result in the systematic development of the TSL economic structure (Januła, Truś, Gutowska, 2011, pp. 250-260).

In order to optimize the entire supply chain and individual logistics processes, modern transport, forwarding and logistics companies often use instruments that help them manage logistics.

Management of logistics with the use of selected instruments help achieve:

a) improvement in the flow of goods to the customer, including:

- creating progressive strategy for a company that contributes to rapid development - optimization of the logistics chain,

- development of a marketing and logistics concept in accordance with the customer's requirements,

- improved information flow,

- fast data transfer;

b) modernization of IT programmes, including:

- implementation of modern IT programs supporting the logistics system,

- automatic recognition of goods using bar codes and RFID readers,

- EDI - electronic data interchange,

- improved warehouse operation using warehouse automation;

c) introduction of innovative management methods, including:

- Just in Time,

- MRP - material requirements planning,

- MRP II - manufacturing resource planning,

- ERP - enterprise resource planning (support with the use of modern technology),

- DRP - distribution resource planning,

- application of the kanban concept - that is, controlling production and general overview of the stocks in the warehouse, 
- application of the kaizen concept - continuous improvement of the enterprise in the entire logistics chain, involving all employees,

- Introduction of ABC and XYZ technique (Mroczko, 2016, pp. 69-73).

Introduction of the above-mentioned tools into the management system of a modern company will result in increased customer satisfaction, competitive advantage, minimisation of time and costs of material and finished goods flow, decrease in potential stock, better use of production potential, reduction of manufacturing costs (more favourable price for the final consumer).

\section{DHL's development strategies}

DHL company was founded in San Francisco in 1969. Its named derived from the first initial of each founder's last name: Adrian Dalsey, Larry Hillblom and Robert Lynn (DHL, 2018). In the years 1970-1980, there could be observed a strong demand for transport of goods by sea from San Francisco to Honolulu. At that time, the biggest difficulty faced by customers was customs clearance, which significantly delayed delivery, and the waiting time generating considerable costs. The founders of DHL, especially one of them, came up with the idea of transporting the necessary documents for customs when shipping by air, which significantly reduced the budget costs, and most importantly, minimized the vessels' turnaround times (DHL, 2018).

Such a solution allowed them to develop their offer. They were the first to enter the new market and became one of the most competitive companies in this industry, which contributed to the significant development of DHL. A few years later, i.e. 1979-2000, DHL opened its offices in Africa and Europe, including Poland. After 10 years of operation, the company has 360 logistic centres and cooperates with over 85,000 customers worldwide. Thanks to having its logistics centres in almost all countries in the world, the company brings a new dimension to customer service and creates new service for them that allow distributions of parcels and global transport, i.e., WorldMail (DHL, 2018).

"WorldMail" is also an international electronic mail service that allows arranging delivery online from a given country at the time convenient for the customer. Moreover, it allows tracking a parcel and determining the lead and delivery time to the customer. In 1984, the company entered the Polish market under the name "DHL Worldwide Express". In order to take control over a bigger sector of the domestic and international shipping industry, the company decided to cooperate with Cargo, a forwarding company. This cooperation strengthened its position on the market and increased competitiveness between it and Poczta Polska (DHL, 2018).

\section{DHL entering the European and Polish courier service market}

In order to keep up with the technological progress around the world that took place at the end of the 20th century, DHL began to invest in its logistics centres. The first goal in the four-year investment programme was to automate every centre, whereas in the next years, the company decided to invest in:

- warehouse equipment,

- the latest computer software,

- fast information flow,

- direct information transfer,

- infrastructure and rolling stock,

- mobile applications for phones and other devices. 
Although the four-year investment programme for 2012-2016 cost almost USD 100 million, it brought substantial benefits for the company, among others, ISO certificates, the award for the implementation of ecological strategies, and purchase of Boeing 757 freighter, thanks to which deliveries took only a day, which in turn contributed to a larger number of customers (DHL, 2018).

At the beginning of the 21st century, DHL joined forces with NWA Cargo to completely take over the entire Asian market and save their customers from having to spend millions of dollars on secure, effective and fast services integrating Asia and the US.

IN 2002, Deutsche Post bought $51 \%$ of DHL's shares, and thus became the principal shareholder of DHL (DHL, 2018).

The constantly developing DHL has become a leader on the international courier service market, and above all in the aviation industry, possessing the latest technology and maintaining high quality of customer service. Constant investments in the company made it possible to improve the entire logistics process and met all customers' requirements, while increasing its competitiveness.

In 1984, DHL Worldwide Express, the biggest delivery company in the world, took advantage of the untapped reserves in the courier service industry and started providing its services on the Polish market. The cooperation between DHL and Cargo, a Polish shipping company, made it possible to take over a significant part of express international courier services and control this part of the courier service sector in Poland (Pliszka, 2008, pp. 113-114).

Since 1989, i.e. the beginning of socio-economic reforms, the courier service market in Poland has been creating an adequate industry structure related to delivery. Free market standards initiated by the Polish government allowed the creation of new domestic courier companies such as:

- Masterlink Express,

- Kurierserwis,

- Stolica,

- Opek.

Removing barriers on the Polish courier service market widened competition exerted by foreign companies, as it attracted the biggest courier companies in the world. Favourable conditions on the Polish market allowed foreign companies to create and develop logistics centres, organizational units or departments, as shown in Table 1 (Pliszka, 2008, pp. 110-116).

Table 1. Representatives of the largest foreign courier companies in Poland

\begin{tabular}{lcccc}
\hline & $\begin{array}{c}\text { Country with } \\
\text { Company name }\end{array}$ & $\begin{array}{c}\text { The year } \\
\text { the company's } \\
\text { registered office }\end{array}$ & $\begin{array}{c}\text { of the establishment } \\
\text { of a branch in Poland }\end{array}$ & Service \\
\cline { 3 - 5 } DHL Worldwide Express & USA & 1984 & local & domestic \\
RGW Express & Germany & 1990 & $\times$ \\
TNT Express Worldwide & The Netherlands & 1992 & $\times$ \\
Airborne Express & USA & 1996 & $\times$ \\
FedEx & USA & 1997 & $\times$ \\
OCS & Japan & 2002 & $\times$ \\
United Parcel Service & USA & 2005 & $\times$ \\
Direct Parcel Distribution & Germany & 2007 & $\times$ \\
\hline
\end{tabular}

Source: Pliszka (2008), pp. 113-114. 
There are 3 branches operating under the DHL brand name:

- DHL Global Forwarding Sp. z.o.0,

- DHL Express Polska Sp. z.o.0,

- DHL Exel Supply Chain Sp. z.0.0 (DHL, 2018).

DHL Global Forwarding was established as a result of a merger of Danzas and Cargoline, which started new and continued previous activities of Deutsche Post World Net under the name DHL Logistics.

The merger of Worldwide and Deutsche Post initiated the creation of DHL Express (Ciesielski, 2005, pp. 148-159).

At the end of 2005, DHL extended its offer with additional economical services of Exel, and thus became the undisputed leader on the Polish courier service market.

DHL Supply Chain specializes mainly in:

- analysing customers' requirements in order to meet them,

- the structure of good storage,

- helping organize the entire supply chain,

- setting goals in the sphere of the company's production activity (DHL, 2018).

In Poland, DHL Express has: registered office in Warszawa; 6 innovative sorting plants ( 3 express and 3 general cargo) among others in: Warszawa, Zabrze, Głuchowo near Poznań; over 40 terminals (including in Przecław near Szczecin); 68 offices; 84 distribution centres; 6 air cargo sorting plants; over 5,000 employees; about 50 customer service centres; 180 DHL Service Points; 3 airplanes; 6 customs agencies; and over 600 connections between terminals (DHL, 2018).

\section{DHL investments as a chance to improve the company's competitiveness}

The most important investment will be the creation of an ultramodern airport terminal in Okęcie for the international shipping market. This investment will cost almost PLN 100 million, and its aim is to summarize the 25 years of operation, as well as increase popularity among its local clients. The terminal in Okęcie will serve numerous functions:

- airport for airplanes with shipments,

- sorting plant for air freight,

- customs,

- standard courier terminal (Duszczyk, 2017).

All these innovations and investments are implemented in order to meet the customers' requirements, and provide them with highest levels of satisfaction when making a delivery with DHL. The most important benefits for the customer include:

- reducing customer service time,

- high quality with relatively low service prices,

- complete handling of shipments,

- all-time tracking of shipments,

- complete control over the transport process (DHL, 2018). 
Research on courier service quality conducted by Polski Instytut Badań Jakości in 2017 included such companies as: DHL, DPD, FedEx, GLS, Inpost, Pocztex, UPS (PIBJA, 2017). Synthetic evaluation revealed high position of DHL in this ranking, which is confirmed by the results presented in Table 2.

The assessment and final evaluation of the final research carried out by Instytut Jakości helped to choose the "best" courier company - i.e. DHL, which, according to the conducted research, may offer the best service conditions, as well as meet and satisfy the expectations of demanding customers.

Table 2. The final assessment of the courier companies research conducted in 2017

\begin{tabular}{cccc}
\hline No. & Company & Result (\%) & Information \\
\hline 1 & DHL & 88.5 & $4.4 /$ Very good \\
2 & Inpost & 86.3 & $4.3 /$ Very good \\
3 & UPS & 85.5 & $4.2 /$ Good \\
4 & Pocztex & 82.6 & $4.0 /$ Good \\
5 & DPD & 81.9 & $4.0 /$ Good \\
6 & GLS & 72.9 & $3.4 /$ Good \\
7 & FedEx & 65.9 & $2.9 /$ Satisfactory \\
\hline
\end{tabular}

Source: PIBJA (2017).

DHL strives to become a modern company that cares not only about their customers, but also the environment in which it operates (DHL, 2018). However, in order to achieve this, it needs significant investment funds, which are shown in Table 3.

Table 3. The estimate of the financial resources needed for further development of DHL until 2025

\begin{tabular}{|c|c|c|c|c|c|}
\hline \multirow[b]{2}{*}{ Detailed list } & \multicolumn{5}{|c|}{ Years } \\
\hline & $\begin{array}{c}2017 \\
\text { (performance) }\end{array}$ & 2018 & 2019 & 2020 & 2025 \\
\hline Income & EUR 14.9 bn & EUR $16.1 \mathrm{bn}$ & EUR 17.5 bn & EUR $19.1 \mathrm{bn}$ & EUR $21.01 \mathrm{bn}$ \\
\hline Costs & EUR 14 bn & EUR $15.1 \mathrm{bn}$ & EUR $16.4 \mathrm{bn}$ & EUR 17.9 bn & EUR $19.7 \mathrm{bn}$ \\
\hline Financial result & EUR $885 \mathrm{~m}$ & EUR 1 bn & EUR $1.1 \mathrm{bn}$ & EUR 1.2 bn & EUR 1.3 bn \\
\hline Net profit & EUR $633 \mathrm{~m}$ & EUR $775 \mathrm{~m}$ & EUR $904 \mathrm{~m}$ & EUR 1 bn & EUR 1.2 bn \\
\hline Own investments $80-90 \%$ & EUR 334 m (80\%) & EUR $350 \mathrm{~m}(82.8 \%)$ & EUR $376 \mathrm{~m}(84.5 \%)$ & EUR 390 m (87.8\%) & EUR $450 \mathrm{~m}(88.9 \%)$ \\
\hline Loans $10-20 \%$ & EUR 67 m (20\%) & EUR $60 \mathrm{~m}(17.2 \%)$ & EUR $58 \mathrm{~m}(15.5 \%)$ & EUR $47.5 \mathrm{~m}(12.2 \%)$ & EUR $50 \mathrm{~m}(11.1 \%)$ \\
\hline
\end{tabular}

Source: own estimate based on the results achieved by $\mathrm{DHL}$.

Assuming that DHL's strategy foresees 8\% change in income and costs between 2017 and 2018, the financial result is projected to be about EUR 1 billion a year, which will generate profits at the level of EUR 775 million. By investing in the further development programme, the company will want to allocate a total of EUR 410 million for further expansion in 2018. 


\section{Conclusions}

The deliberation presented in this article can lead to the following conclusions:

1. Logistics service can be defined as commercial performance of forwarding, transport and storage services as well as related services, and processes supporting the flow of goods between the links in the supply chain.

2. Modern logistics management helps improve circulation of goods, information services regarding logistics processes, and competitiveness of logistics companies.

3. DHL entering the Polish courier service market in 1984 significantly increased competitiveness on this market.

4. The synthetic evaluation of courier service quality from 2017 revealed a very good assessment of the services provided by DHL, as compared to services provided by Inpost, UPS, Pocztex and DPD.

5. Improving the offer and strengthening the competitive position of $\mathrm{DHL}$ requires spending approx. EUR 410 million in 2018, and approx. EUR 500 million in 2020.

\section{References}

Blaik, P. (2001). Logistyka. Koncepcja zintegrowanego zarządzania. Warszawa: PWE.

Ciesielski, M. (2005). Rynek usług logistycznych. Warszawa: Difin.

DHL (2018). Retrieved from: http://wap.dhl.com/info/history.html.

Duszczyk, M. (2017). DHL postawił na Okęcie. I przegra? Retrieved from: http://www.rp.pl/Biznes/310099875-DHL-postawil-naOkecie-l-przegra.html.

Januła, E., Truś, T., Gutowska, Ż. (2011). Spedycja. Warszawa: Difin.

Mroczko, F. (2016). Logistyka. Wałbrzych: Wydawnictwo Wyższej Szkoły Finansów i Zarządzania w Białymstoku.

PIBJA (2017). Firmy kurierskie 2017: ocena obsługi, jakości, czasu realizacji oraz porównanie cen. Retrieved from: www.badaniajakosci. pl/tests/firmy-kurierskie-2017-ocena-obslugi-jakosci-casu-realizacji-oraz-porownanie-cen/.

Pliszka, M. (2008). Rynek usług kurierskich w Polsce. Słupsk: Słupskie Prace Geograficzne, Akademia Pomorska. Retrieved from: https://spg.apsl.edu.pl/baza/wydawn/spg05/pliszka.pdf.

Rosa, G., Jedliński, M., Chrąchol-Barczyk, U. (2017). Marketing usług logistycznych. Warszawa: Beck.

Rydzkowski, W. (2011). Usługi logistyczne. Poznań: Instytut Logistyki i Magazynowania.

Szpon, J., Dembińska-Cyran, I., Wiktorowska-Jasik, A. (2005). Podstawy logistyki. Szczecin: Stowarzyszenie Naukowe Instytut Gospodarki i Rynku.

Więcerzycki, M. (2009). Zintegrowane systemy informacyjne. In: M. Ciesielski (ed.), Instrumenty zarządzania łańcuchami dostaw. Warszawa: PWE.

Cite this article aS: Perenc, J. (2018). Logistics as a tool to improve the competitiveness of DHL services. European Journal of Service Management, 3 (27/2), 339-346. DOI: 10.18276/ejsm.2018.27/2-41. 